\title{
Intranasal Ketamine
}

National Cancer Institute

\section{Source}

National Cancer Institute. Intranasal Ketamine. NCI Thesaurus. Code C71709.

An intranasal formulation of the synthetic cyclohexanone ketamine with analgesic and anesthetic activities. Although its mechanism of action is not well understood, ketamine appears to non-competitively block N-methyl-D-aspartate (NMDA) receptors and agonistically bind to and activate opioid mu and sigma receptors, thereby reducing pain perception, inducing sedation, and producing dissociative anesthesia. 